Report from America

Bernard Towers University of California, Los Angeles, USA

\section{The impact of the California Natural Death Act}

The 'Natural Death Act' of the State of California was the first of its kind in the USA, and became law on I January 1977. The legislative assemblies of approximately 40 other States in the Union have made, or are making, efforts to pass similar legislation for the communities under their jurisdiction. Since California was the first, it is worth while to look at some of the discernible effects of the legislation, and to provide for British readers a list of references to relevant publications.

A recent meeting of the UCLA Medicine and Society Forum (see fournal of Medical Ethics (1975) 1:159-160 for information about this series) was entitled 'California's Natural Death Act: What Difference Has It Made ?' ' The proceedings are recorded on videotape, and consist of statements, questions and open discussion between the present writer (as moderator), three panelists and the audience. The panelists were: M S Lipton, the Legal Adviser to the Assembly Health Committee, about whom its chairman and author of the Bill (The Hon Barry Keene) recently said, 'without the tireless efforts and creative energy of Steve Lipton, the Natural Death Act . . . would not have been possible'; E S Shneidman the well-known author, and Professor of Thanatology at UCLA; and $\mathrm{W} \mathrm{J}$ Winslade, Lecturer in Law and Psychiatry at UCLA and recent author of a very perceptive article on the Act. ${ }^{8}$ The session started, as usual, with the reading of an agreed statement as follows:

'On I January 1977, the Natural Death Act became effective; it was the first law in the USA to establish formal procedures to enable competent adults to instruct their physicians to withhold or withdraw useless life-sustaining procedures in cases of incurable injury, disease or illness. Similar legislation has been proposed in forty states and comparable laws have been passed in seven states. Numerous factors account for these legal developments, including: concern that non-beneficial medical technology is often used to prolong the dying process; increased awareness of medical consumers who wish to exercise personal control over their medical care; and uncertainty among physicians about their legal liabilities if medical procedures, even useless ones, are discontinued. All these issues were evident in the case of Karen
Anne Quinlan which increased pressure fote legislative action.

Much public controversy and subsequent politi户 cal compromise affected the final version of the California Natural Death Act. As a result, critic్্ have claimed that the law contains ambiguous language, creates bureaucratic burdens for patient and physicians and has very limited applicability Supporters of the Act, however, argue that the law has clarified the rights and responsibilities of patients and physicians, strengthened the patient physician relationship, increased public awarenes $\vec{s}$ of the need for open discussion of death and dying and contributed to the creation of an atmosphere for treating the terminally ill with personal respecte and concern. ${ }^{1}$,

The bibliographic references for the occasiow were carefully chosen by the moderator an panelists, to represent the 'best of the crop' as of the time of preparation for the session. They ar given below as references. ${ }^{2-8}$

The California law went through many change $\overrightarrow{\vec{E}}$ in its passage through both houses. As a result i was strengthened in a few respects, but weakened in many others. The American political process is. very complex, and I still find, after nearly eight years of residency, some confusion in my min $\overrightarrow{\mathbb{P}}$ about what sometimes seem to be multiple oli응 garchical systems operating under the cloak of democracy. There certainly is a system of 'check? and balances', but by and large political clout seems to be held by those individuals or groups which can either:

a) Put on the best advertisement campaign through a media-system which reeks of influence andr hypocrisy;

b) Apply political pressure through the systen of 'lobbying' (often at great initial expense to the backers, through the financial return may be extraordinary if you 'win out');

c) Exercise control over legislators themselves? by astute use of sticks and carrots.

Sometimes one is tempted to ask about thiso system, as one used to do about the British system 'when, oh when, will we ever see a free vote?'

Whatever the political pressures and specific circumstances, the Natural Death Act (Assembly? Bill 3060) was amended on no fewer than nine occasions between the time of its introduction byo 
Assemblyman Keene, Chairman of the Health Committee of the Assembly, on 13 February 1976, its passage through the Assembly on I 7 June 1976, and its passage through the Senate on 26 August 1976. It was signed into law by Governor Brown on 30 September 1976 and came into effect on I January 1977. The Governor only signed after much heart-searching and consideration of a request from his own State Department of Health that he should veto it. For the rationale behind the objections see Lebacqz. ${ }^{9}$

The most profound effect of the new law has been to stimulate discussion and debate in many parts of the society and at many different levels. Curiously enough, discussion within the medical profession has been muted. There are some records of attempts to educate in these areas (as, for instance by Dr Winslade and the writer, who have given joint presentations at UCLA both to firstyear medical students and to Pediatric 'Grand Rounds' - by which term is meant the weekly gathering of the whole Department - students, house-staff, faculty and community-practitioners). But, generally speaking, physicians have been loath to come out and speak up about issues that must concern them deeply even if only occasionally.

\section{Meetings attended}

Major meetings known to, and in most cases attended or addressed by, your correspondent include the following. Others are listed by Keene ${ }^{3}$ :

I. 'Achieving a Personal Death'. 17-18 June 1977, in Los Angeles, sponsored by the Euthanasia Educational Council from its national office in New York. This two-day symposium involved many nationally-known speakers, and attracted an audience, with many different views, of about 300 . It has been pointed out repeatedly by Keene ${ }^{3}$ that the Bill expressly excludes active euthanasia:

'The Act shall not be construed to condone, authorise, or approve mercy killing or to permit any affirmative act or omission to end life other than to permit the natural process of dying. As far as can be determined, this was the first statutory pronouncement in this country explicitly rejecting the concept of active and involuntary euthanasia. It serves as a reminder to physicians, patients, and the public of the narrow purpose of the Act and the reverence which we all share for life. ${ }^{3}$,

It may be that that is the voice of the politician, because doubtless some will regard this provision (the result, undoubtedly, of lobbying during the political process of passage of a Bill) as evidencing strength (as Keene seems to suggest), and some as evidencing weakness to the point of emasculation. But at least it provides for a point of departure for that discussion which has been one of the major responses to the passage of the Act.
2. A series of two Conferences and three Workshops sponsored by the National Conference of Christians and Jews (Southern California Region). These were held in Los Angeles in the University of Southern California (USC), Pepperdine University, Loyola University, and the University of California at Los Angeles (UCLA), and were supported by the California Council for the Humanities in Public Policy with funds provided by the National Endowment for the Humanities. The result of these meetings was a large increase in the number of persons actively involved in analysing the implications of the Act and in suggesting possible Amendments which might, in due course, be channelled through the legislative bodies of the State. That such amendments are desirable has been adequately demonstrated not only at the meetings listed above, and in a number of radio broadcasts (television stations have so far been rather 'gun-shy' in this area), but also at the conference described below.

3. The Tenth Euthanasia Conference held in New York on Io December 1977, during which the California legislation was again subjected to critical appraisal. This Conference carried the title 'Toward a Good Death-Developments Over a Decade-A Look Ahead', and during it an appeal was made for a new name for the organisation that might better indicate that it is concerned with education about the meaning of a 'good death' rather than with concern for promulgating (which it is not) 'active euthanasia'.

\section{An account of the law}

A succinct account of the law has been given by the Executive Director of the Northwest Institute of Ethics and the Life Sciences. Many such nonprofit organisations have come into being in recent years and this one is based in Seattle, Washington:

'The California law provides a legal directive (to physicians) by which the signer's desire that life-sustaining procedures be withdrawn or withheld when they will serve only to postpone the moment of death are made clear. Only adults of sound mind may execute such a directive. If an individual has been diagnosed by his attending physician (and confirmed by a second physician) as being terminally ill, he then becomes a 'qualified patient', and any directive he then executes is legally enforceable.

If the signer is not a qualified patient at the time of execution, the directive is not legally binding but only advisory to the physician. The attending physician may give weight to the directive as evidence of the patient's directions and may consider other factors, such as information from the affected family or the nature of the patient's illness, injury, or disease in determining whether the 
totality of circumstances justify effectuating the directive. If a person executes a directive and subsequently is diagnosed as terminally ill he must re-execute a directive in order that it be legally binding. The directive remains in force for five years unless revoked by the patient, and may not be enforced until at least I4 days after its execution. Witnesses are required, and individuals with specified conflicts of interest may not be witnesses. Revocation is a simple procedure - it can be verbal, written or achieved by destroying the directive'. ${ }^{10}$

As will be seen, some patients (and those the most deserving) will find that it is either impossible or very difficult for them to sign a valid directive. Re-signing the document after becoming 'qualified', and having it properly witnessed by someone also qualified according to the restrictions of the law, compounds the difficulties for many. The fact that the physician has the responsibility to determine that the directive is a validly-executed and enforceable document is regarded by some as placing an undesirable burden on him.

The responses (II2 or 66 per cent) of those 168 physicians in California who had ordered a minimum of roo copies of the Directive to Physicians prior to September 1977, were analysed for the California Medical Association by its 'Committee on Evolving Trends in Society Affecting Life.' 2 No information is yet available about practices in hospitals, where copies of the directive are probably being produced 'on site'. Incidentally, a big drawback to the Bill was its failure to provide a mechanism for distribution of its findings other than by personal request to the state capital.

Of the II2 physicians who responded to the questionnaire only six stated that the Natural Death Act had resulted in a change in the way in which they practised medicine, but the Committee judged that the 'change' had been merely a reinforcement of practice modes. Fifty-three doctors, as represented by 19 respondents, had made use of the directive signed by an estimated 67 patients. About 50 per cent of the respondents did not believe that the Act requires revision, and most of the suggestions for revision that were made were for changes that had been well-debated at the time the Bill was being considered by the legislature. The principal benefit that emerged from answers from this relatively early and small sample, was that the simple existence of the legislation, and the fact that there is a Directive to talk about, have been positive forces in encouraging patients and their families to discuss the subject of terminal illness.

\section{End of the taboo?}

For many decades death has been a taboo topic in America. Even before the California NDA was passed it had come out of the closet, and had even become something of an 'in' topic in colleges and universities. Courses based on Kübler-Ross have so stressed the five stages of dying and their propeT sequence that new anxieties have been createf these anxieties are now being addressed by simple 'how to die' books, and by a crop of earnest 'therapists' who will help you retrace your steps 1 If you got out of sequence with your stages. We axe doubtless in for a lot of nonsense of that sort, anc the NDA is bound to contribute to the nonsens by legitimating it in some ways.

However, as pointed out by Winslade, 8 the primary significance of the Act at the present tims may lie in its symbolic value, in that it makes clear the right of a patient (under certain and undugf restricting provisions, it is true) to keep his or het autonomy and control over what may and may not be done to him or her, right up until the last. Keene has pointed out ${ }^{3}$ this right is nothing newf It had been much neglected by patients, and haet been (and still is) much abused by physicians. that were not so, the California Natural Death Act would not have been perceived as necessary, and would not have been passed into law. Now we must set about improving it, and it would surely bes better to do so by discussion and legal amendmem rather than through action taken in the courts.

\section{References}

${ }^{1}$ UCLA Medicine and Society Forum (1978). Ca fornia's Natural Death Act: What Difference Has it Made? January 26, videotape recording.

${ }^{2}$ California Medical Association (1977). Survey Results Following One Year's Experience with The Natur Death Act, September I, 1976 - August 31, 1979. unpublished report of the C.M.A., San Franciscegs California.

${ }^{3}$ Keene, Barry (1977). The Natural Death Act: $A$ We Baby Check-up on its First Birthday, address to the New York Academy of Science's Conference of Brain Death, November I6-18, 1977 (to be pube lished).

${ }^{4}$ Meyers, D W (1977). The California Natural Deat Act: A Critical Appraisal, California State B fournal, 52, 326.

${ }^{5}$ Randall, M W (1977). The Right to Die a Naturfy Death: a Discussion of In Re Quinlan and the Natural Death Act, Cincinnati Law Revies 46, 192.

6 Shneidman, Edwin S (1977). Aspects of the Dying Process, Psychiatric Annals, 7, 25.

7 Steinberg, M I (1977). The California Natural Deat Act - A Failure to Provide for Adequate Patiexor Safeguards and Individual Autonomy, Connecticut Law Review, 9, 203.

${ }^{8}$ Winslade, W J (1977). Thoughts on Technology an Death: An Appraisal of California's Natural Dea Act, De Paul University Law Review, 26, 717.

- Lebacqz, Karen (1977). Commentary on Nature Death, Hastings Center Report, 7, I4.

${ }^{10}$ Raible, Jane A (1977). The Right to Refuse Trea@ ment and Natural Death Legislation, Medicolege News, 5 (4), 6. 